\title{
Familial aggregation of longevity in giant cell arteritis and polymyalgia rheumatica
}

\author{
Marcin Milchert $^{1}$ (D) Marek Brzosko ${ }^{1}$ iD
}

Received: 3 April 2020 / Accepted: 11 July 2020 / Published online: 18 July 2020

(C) The Author(s) 2020

\begin{abstract}
The long-term mortality in giant cell arteritis (GCA) and polymyalgia rheumatica (PMR) is unexpectedly decreased or at least not increased regardless of several mortality risk factors that these diseases share with other chronic immune-mediated rheumatic diseases. The genetic and immunological profile of PMR/GCA patients is unique, therefore, the hypothesis that this profile provides some survival advantage to PMR/GCA patients should be considered. The longevity is a phenomenon that was demonstrated to be familial. The familial aggregation of longevity can be studied by analysis of life expectancy in family members. Here we test the hypothesis of the aggregation of an increased longevity in the families of PMR/GCA patients. We compared the age of death of 358 parents of 179 PMR and GCA patients with corresponding data retrieved from 506 parents of 253 randomly collected age and sex-matched controls. The number of nonagenarian ( $\geq 90$-year -old) mothers of PMR/GCA patients was significantly higher $(\mathrm{OR}=2.34,95 \% \mathrm{CI} 1.11-11.95, p<0.0005)$ vs controls. Both nonagenarian parents were found in 6 patients (3.35\%) and none in the control cohort $(\mathrm{OR}=8.77,95 \% \mathrm{CI} 2.26-405.10, p=0.003)$. Our data suggest the familial aggregation of nonagenarians in PMR/GCA patients.
\end{abstract}

Keywords Longevity $\cdot$ Mortality $\cdot$ Giant cell arteritis $\cdot$ Polymyalgia rheumatica

\section{Introduction}

Giant cell arteritis (GCA) and polymyalgia rheumatica (PMR) are closely related, chronic immune-mediated rheumatic diseases, limited to elderly patients. The long-term mortality is at least not increased in GCA and PMR [1-5] or even decreased compared to the general population [6-9]. It is surprising because these diseases share several risk factors of increased mortality with other immune-mediated rheumatic diseases. The decrease in a lifespan in GCA was rarely observed [10,11] or was minimal [12]. Inpatient GCA mortality was also reported to be decreased when compared to the matched inpatient population [13]. In addition, in isolated PMR (PMR without concomitant GCA) an increased survival was observed $[2,14]$.

Marcin Milchert

marcmilc@hotmail.com

Marek Brzosko

brzoskom@pum.edu.pl

1 Department of Rheumatology, Internal Medicine, Geriatrics and Clinical Immunology, Pomeranian Medical University in Szczecin, ul Unii Lubelskiej 1, 71-252 Szczecin, Poland
The genetic background (high prevalence of these diseases in special populations, association with special HLA antigen) and immunological profiles (with strongly pronounced autoinflammatory component) of PMR/GCA patients' are unique $[6,14,15]$, therefore, we hypothesize that these might correlate with some survival advantage. Explanation of this potential advantage would imply a need for including some genetic or behavioural factors. Longevity is a phenomenon that was demonstrated to be familial, and is associated with the inherited longevity genes, the survival-promoting genes or health-promoting behaviours. The family members of long-lived subjects have a survival advantage. Familial aggregation of longevity can be studied by analysis of life expectancy in family members [16-18].

We focused on the unexpected survival advantage in PMR/GCA and tested the hypothesis of aggregation of an increased longevity in PMR/GCA patients and their families. 


\section{Materials and methods}

Information was retrieved from patients diagnosed in the single reference center for GCA/PMR between 2016 and 2019. We collected information from 179 consecutive PMR and GCA patients (aged $75.6 \pm 8.7$ years; min 52, $\max$ 97, 125 women, 54 men, 124 GCA, 129 PMR) and 253 controls (aged 76.4 \pm 9.4 years; $\min 51$, $\max 98,153$ women, 100 men). Age of death of 358 deceased parents of patients and 506 deceased parents of controls was noted. Age and sex-matched controls were randomly collected from inadvertently met people without the diagnosis of PMR/GCA, in the same time period and region $(N=112)$, recruited from patients' spouses without the diagnosis of PMR/GCA $(N=42)$, and retrieved from open-access national polish genealogy database [19] $(N=99$, the database enables collection of information on age and sex of current population group of people and their parent's age of death, that were consecutively extracted). Nine patients were not included because of unawareness of their parents' age of death.

The diagnosis of GCA/PMR was confirmed during at least one follow up visit within 1-6 months. GCA patients met 1990 ACR classification criteria [20] or presented GCA manifestations together with large vessel vasculitis confirmed by ultrasound, computed tomography and/or PET-CT. PMR patients met EULAR/ACR classification criteria [21] Isolated PMR presented no clinical manifestations of GCA and no temporal and axillary vasculitis that were excluded by ultrasound.

We compared the age of death of parents of PMR and/ or GCA patients (including isolated PMR subgroup) with controls. The logistic regression and $t$ Student's test were applied due to a normal distribution that was checked by Kołmogorow-Smirnow test. The Spearman correlation coefficient was additionally used. $p<0.05$ was considered significant. Statistical analyses were performed with STATA software (version 12.0; StataCorp).

The additional analysis was performed vs. the control group recruited from age and sex-matched patients (289 parents of 145 patients) referred with suspected PMR/GCA but diagnosed with rheumatoid arthritis $(N=37$ patients $)$, osteoarthritis $(N=23)$, other rheumatic conditions $(N=19)$, or no rheumatic disease $(N=39)$.

The study was accepted and patients' consent was waived in accordance with the Pomeranian Medical University ethical committee decision KB-0012/170/06/19.

\section{Results}

The number of nonagenarian ( $\geq 90$-year-old) mothers of both female and male PMR/GCA patients was significantly higher in the following cohorts: GCA/PMR (Table 1), isolated PMR (without concomitant GCA, OR =7.52, 95\% CI 2.81-20.33, $p<0.00005)$, PMR (OR=4.73, 95\%CI 2.04-11.59, $p<0.00005)$, GCA (OR $=4.13,95 \% \mathrm{CI}$ $1.73-10.32, p=0.0002$ ), and isolated GCA (without concomitant PMR, OR=6.08, 95\%CI 2.10-17.28, $p<0.0000$ ) compared to the population-based controls. No difference in the number of nonagenarian mothers between the isolated GCA vs. PMR (OR = 1.29, 95\%CI 0.49-3.15, $p=0.5550)$ nor isolated PMR vs. GCA $(\mathrm{OR}=1.82,95 \% \mathrm{CI}$ 0.75-4.33, $p=0.1368$ ) was found. There were significantly fewer nonagenarian fathers compared to the controls (Table 1.), with a lower significance compared to an increased number in mothers (Table 1 and 2). Both nonagenarian parents were found in six patients $(3.35 \%)$ and none in the controls. No significant difference in the mean length of life between PMR/GCA parents vs. controls was found (Table 3.).

Table 1 Number of nonagenarians ( $\geq 90$-years-olds) in parents of PMR/GCA patients

\begin{tabular}{|c|c|c|c|c|c|c|}
\hline & Parents age & PMR/GCA $(N=179)$ & Controls $(N=253)$ & OR & $95 \% \mathrm{CI}$ & $p$ \\
\hline \multirow[t]{2}{*}{ Mothers } & $<90$ & $148(82.68 \%)$ & $243(96.05 \%)$ & & & \\
\hline & $\geq 90$ & $31(17.32 \%)$ & $10(3.95 \%)$ & 2.34 & $1.11-11.95$ & $<0.0005$ \\
\hline Fathers & $\begin{array}{l}<90 \\
\geq 90\end{array}$ & $\begin{array}{l}161(89.94 \%) \\
18(10.06 \%)\end{array}$ & $\begin{array}{l}203(80.24 \%) \\
50(19.76 \%)\end{array}$ & 0.45 & $0.24-0.83$ & 0.0064 \\
\hline One of parents & $\begin{array}{l}<90 \\
\geq 90\end{array}$ & $\begin{array}{l}136(75.98 \%) \\
43(24.02 \%)\end{array}$ & $\begin{array}{l}193(76.28 \%) \\
60(23.72 \%)\end{array}$ & 1.02 & $0.63-1.63$ & 0.9412 \\
\hline Both parents & $\begin{array}{l}<90 \\
\geq 90\end{array}$ & $\begin{array}{l}173(96.65 \%) \\
6(3.35 \%)\end{array}$ & $\begin{array}{l}253(100.00 \%) \\
0(0 \%)\end{array}$ & 8.77 & $2.26-405.10$ & 0.003 \\
\hline Mothers of female patients & $\begin{array}{l}<90 \\
\geq 90\end{array}$ & $\begin{array}{l}105(84 \%) \\
20(16 \%)\end{array}$ & $\begin{array}{l}149(97 \%) \\
4(3 \%)\end{array}$ & 7.1 & $2.27-29.19$ & 0.0001 \\
\hline Mothers of male patients & $\begin{array}{l}<90 \\
\geq 90\end{array}$ & $\begin{array}{l}43(80) \\
11(20 \%)\end{array}$ & $\begin{array}{l}94(94 \%) \\
6(6 \%)\end{array}$ & 4.01 & $1.25-13.97$ & 0.0066 \\
\hline
\end{tabular}

$G C A$ giant cell arteritis, $P M R$ polymyalgia rheumatica, $N$ number of all parents 
Table 2 Correlation between the number of nonagenarians ( $\geq 90$-years -olds) in parents in different PMR/GCA subsets

\begin{tabular}{|c|c|c|c|c|}
\hline & & $N$ & $\begin{array}{l}\text { Correlation } \\
\text { coefficient }\end{array}$ & $p$ \\
\hline \multirow[t]{4}{*}{ Number of nonagenarians in mothers } & GCA & 124 & -0.19 & 0.0002 \\
\hline & Isolated GCA (without concomitant PMR) & 50 & $-0,24$ & 0.00002 \\
\hline & PMR & 129 & -0.21 & 0.00003 \\
\hline & Isolated PMR (without concomitant GCA) & 55 & -0.29 & $<0.000005$ \\
\hline \multirow[t]{4}{*}{ Number of nonagenarians in fathers } & GCA & 124 & 0.16 & 0.0016 \\
\hline & Isolated GCA (without concomitant PMR) & 50 & 0.07 & 0.1975 \\
\hline & PMR & 129 & 0.13 & 0.0087 \\
\hline & Isolated PMR (without concomitant GCA) & 55 & 0.03 & 0.5830 \\
\hline
\end{tabular}

$G C A$ giant cell arteritis, $P M R$ polymyalgia rheumatica, $N$ number of all parents

Table 3 Length of life of parents of PMR/GCA patients and controls

\begin{tabular}{|c|c|c|c|c|c|}
\hline & \multicolumn{4}{|c|}{ Length of life \pm SD $(\min -\max )$} & \multirow[b]{2}{*}{$p$} \\
\hline & $\begin{array}{l}\text { PMR/GCA } \\
(N=179)\end{array}$ & $\begin{array}{l}\text { GCA } \\
(N=124)\end{array}$ & $\begin{array}{l}\text { Isolated PMR } \\
\text { (without concomitant } \\
\text { GCA) } \\
(N=55)\end{array}$ & $\begin{array}{l}\text { Controls } \\
(N=253)\end{array}$ & \\
\hline All parents & $74.6 \pm 15.6$ & $73.7 \pm 15.6$ & $74.6 \pm 17.0$ & $76.2 \pm 11.3$ & $>0.05$ \\
\hline Fathers & $71.2 \pm 15.9$ & $70.1 \pm 15.8(30-100)$ & $73.8 \pm 16.1(30-96)$ & $79.8 \pm 10.7(38-99)$ & $>0.05$ \\
\hline Mothers & $77.9 \pm 14.5$ & $77.3 \pm 14.5(29-99)$ & $79.2 \pm 14.5(30-97)$ & $72.5 \pm 10.8(40-96)$ & $>0.05$ \\
\hline
\end{tabular}

$G C A$ giant cell arteritis, $P M R$ polymyalgia rheumatica, $N$ number of all parents
The additional analysis vs control group recruited from the subjects referred with the suspected but excluded PMR/ GCA revealed an increase in the number of nonagenarian parents of isolated PMR patients $(\mathrm{OR}=2.10,95 \% \mathrm{CI}$ $1.11-3.94, p=0.0121)$.

\section{Discussion}

Previous studies have attempted to explain the phenomenon of increased life expectancy in PMR/GCA pointing to a closer medical surveillance of patients, i.e., better management of comorbidities, including cardiovascular disease [2, 13, 14]. However, such favourable effects were not reported in other immune-mediated rheumatic conditions, which in contrast have reduced life expectancy [6]. In addition, increased life expectancy in PMR/GCA patients is observed regardless of harmful effects of systemic inflammation, adverse effects of therapy [13], and a higher risk of dissecting aortic aneurysm development [12]. PMR/GCA patients seem not to be resistant to the disease-related risk factors because mortality within the first 2 years following diagnosis was reported to be increased suggesting cause-specific effect [1]. Therefore, we find it important to consider the additional factors that may favour survival in PMR/GCA patients.
An accepted model of studies of longevity encompass the analysis of environmental and genetic factors in nonagenarians ( $\geq 90$-years -olds) and centenarians $(\geq 100$-years olds) $[16,17]$. The family members of the long-lived subjects have a survival advantage. Longevity was demonstrated to be at least partially inherited in mitochondrial DNA [16, 17] which is transferred by mothers. This remains in line with our observation of an increase in the number of nonagenarian mothers of PMR/GCA patients. Interestingly, the combination of nonagenarian father and mother was highly more common in PMR/GCA compared to the controls. In previous studies, combined parental longevity was reported to be associated with a decreased all-cause mortality [18].

In addition, genetic regulation of longevity may be indirect, regulating susceptibility to age-related diseases i.e., cardiovascular disease [18]. This mechanism might be considered in GCA patients in whom cardiovascular profile was demonstrated unexpectedly favourable [22]. However, we were not able to compare cardiovascular disease and medical surveillance between our patients and controls to further investigate possible explanations for our finding. High intensity of innate immune activation in elderly patients with PMR/GCA is frequently surprising, questioning the process of downregulation of immune responses known as"immunoaging" in these patients. We speculate that unique immunologic profile (i.e., strong innate immunity 
responses) of PMR/GCA patients might potentially influence specific mortality causes. For example, it could impact lifethreatening infections or neoplasms (their prevalence was discussed in PMR/GCA with conflicting results) [1]. Still, the previously favoured theory of "closer medical surveillance of PMR/GCA patients" favouring PMR/GCA patients survival cannot be excluded based on our observation. However, the decreased number of nonagenarian fathers of our patients remains unexplained. The correlation coefficient of decreased number of nonagenarian fathers was lower compared to increase in mothers and combination of nonagenarian parents. Studies in larger groups are required.

The survey method of data extraction may be considered a limitation of our study. However, only a few patients were unaware of their parents' age at death. A strength of the study was that results were consistent in both isolated PMR and isolated GCA - both diseases share a genetic background. In addition, analysis in an additional control group recruited from patients with GCA mimics confirmed increased longevity of parents of patients with isolated PMR.

Previous data on unexpectedly low long-term mortality in PMR/GCA deserve attention. We found a familial aggregation of longevity in PMR/GCA patients by demonstrating an increased number of nonagenarian ( $\geq 90$-year- old) mothers and both nonagenarian parents of PMR/GCA patients. Further studies warrant confirming our finding.

Acknowledgments We thank Dr. Maciej Markiewski for critically revising this manuscript.

Funding No funding.

\section{Compliance with ethical standards}

Conflict of Interest The authors declared that they have no conflict of interest.

Ethical approval Local ethical committee decision KB-0012/170/06/19.

Human participants All procedures performed in studies involving human participants were in accordance with the ethical standards of the institutional and/or national research committee and with the 1964 Helsinki declaration and its later amendments or comparable ethical standards.

Informed consent The study was accepted and patients' consent was waived in accordance with Pomeranian Medical University ethical committee decision KB-0012/170/06/19.

Open Access This article is licensed under a Creative Commons Attribution 4.0 International License, which permits use, sharing, adaptation, distribution and reproduction in any medium or format, as long as you give appropriate credit to the original author(s) and the source, provide a link to the Creative Commons licence, and indicate if changes were made. The images or other third party material in this article are included in the article's Creative Commons licence, unless indicated otherwise in a credit line to the material. If material is not included in the article's Creative Commons licence and your intended use is not permitted by statutory regulation or exceeds the permitted use, you will need to obtain permission directly from the copyright holder. To view a copy of this licence, visit http://creativecommons.org/licenses/by/4.0/.

\section{References}

1. Hill CL, Black RJ, Nossent JC et al (2017) Risk of mortality in patients with giant cell arteritis: a systematic review and meta-analysis. Semin Arthritis Rheum 46:513-519. https://doi. org/10.1016/j.semarthrit.2016.08.015

2. Gran JT, Myklebust G, Wilsgaard T et al (2001) Survival in polymyalgia rheumatica and temporal arteritis: a study of 398 cases and matched population controls. Rheumatology 40:1238-1242. https://doi.org/10.1093/rheumatology/40.11.1238

3. Mohammad AJ, Nilsson JA, Jacobsson LT et al (2015) Incidence and mortality rates of biopsy proven giant cell arteritis in southern Sweden. Ann Rheum Dis 74:993-997. https://doi.org/10.1136/ annrheumdis-2013-204652

4. Matteson EL, Gold KN, Bloch DA et al (1996) Long-term survival of patients with giant cell arteritis in the American college of rheumatology giant cell arteritis classification criteria cohort. Am J Med 100:1936. https://doi.org/10.1016/S0002-9343(97)89458-2

5. Ninan J, Nguyen AM, Cole A et al (2011) Mortality in patients with biopsy-proven giant cell arteritis: a South Australian population-based study. J Rheumatol 38:22157. https://doi.org/10.3899/ jrheum.101254

6. Garen T, Lerang K, Hoffmann-Vold AM et al (2019) Mortality and causes of death across the systemic connective tissue diseases and the primary systemic vasculitides. Rheumatol (Oxford) 58:313-320. https://doi.org/10.1093/rheumatology/key285

7. Bengtsson BA, Malmvall BE (1981) Prognosis of giant cell arteritis including temporal arteritis and polymyalgia rheumatica. a follow-up study on ninety patients treated with corticosteroids. Acta Med Scand 209:337-345. https://doi. org/10.1111/j.0954-6820.1981.tb11604.x

8. Andersson R, Malmvall BE, Bengtsson BA (1986) Long-term survival in giant cell arteritis including temporal arteritis and polymyalgia rheumatica. A follow-up study of 90 patients treated with corticosteroids. Acta Med Scand 220:361-364. https://doi. org/10.1111/j.0954-6820.1986.tb02778.x

9. Gonzalez-Gay MA, Blanco R, Abraira V et al (1997) Giant cell arteritis in Lugo, Spain, is associated with low longterm mortality. J Rheumatol 24:21716

10. Uddhammar A, Eriksson AL, Nyström L et al (2002) Increased mortality due to cardiovascular disease in patients with giant cell arteritis in northern Sweden. J Rheumatol 29:737-742

11. Crow RW, Katz BJ, Warner JE et al (2009) Giant cell arteritis and mortality. J Gerontol A Biol Sci Med Sci 64:3659. https://doi. org/10.1093/gerona/gln030

12. Baslund B, Helleberg M, Faurschou M et al (2015) Mortality in patients with giant cell arteritis. Rheumatol (Oxford) 54:139-143. https://doi.org/10.1093/rheumatology/keu303

13. Unizony S, Menendez ME, Rastalsky $\mathrm{N}$ et al (2015) Inpatient complications in patients with giant cell arteritis: decreased mortality and increased risk of thromboembolism, delirium and adrenal insufficiency. Rheumatol (Oxford) 54:1360-1368. https://doi. org/10.1093/rheumatology/keu483

14. Myklebust G, Wilsgaard T, Jacobsen BK et al (2003) Causes of death in polymyalgia rheumatica. A prospective longitudinal study of 315 cases and matched population controls. Scand J Rheumatol 32:38-41. https://doi.org/10.1080/03009740310000382 
15. McGonagle D, McDermott MF (2006) A proposed classification of the immunological diseases. PLoS Med 3:e297. https://doi. org/10.1371/journal.pmed.0030297

16. Niemi AK, Moilanen JS, Tanaka M et al (2005) A combination of three common inherited mitochondrial DNA polymorphisms promotes longevity in Finnish and Japanese subjects. Eur J Hum Genet 13:166-170. https://doi.org/10.1038/sj.ejhg.5201308

17. Deluty JA, Atzmon G, Crandall J et al (2015) The influence of gender on inheritance of exceptional longevity. Aging (Albany NY) 7:412-418. https://doi.org/10.18632/aging.100763

18. Atkins JL, Pilling LC, Ble A et al (2016) Longer-lived parents and cardiovascular outcomes: 8-year follow-up in 186,000 UK. Biobank Participants J Am Coll Cardiol 68:874-875. https://doi. org/10.1016/j.jacc.2016.05.072

19. https://www.sejm-wielki.pl/. Accessed 1 June 2019

20. Hunder GG, Arend WP, Bloch DA et al (1990) The american college of rheumatology 1990 criteria for the classification of vasculitis. Introduction Arthritis Rheum 33:1065-1067. https:// doi.org/10.1002/art.1780330802

21. Dasgupta B, Cimmino MA, Maradit-Kremers H et al (2012) 2012 provisional classification criteria for polymyalgia rheumatica: a European league against rheumatism/American college of rheumatology collaborative initiative. Ann Rheum Dis 71:484-492. https://doi.org/10.1136/annrheumdis-2011-200329

22. Udayakumar PD, Chandran AK, Crowson CS et al (2015) Cardiovascular risk and acute coronary syndrome in giant cell arteritis: a population-based retrospective cohort study. Arthritis Care Res (Hoboken) 67:396-402. https://doi.org/10.1002/acr.22416

Publisher's Note Springer Nature remains neutral with regard to jurisdictional claims in published maps and institutional affiliations. 